\title{
Opening Remarks by Elinor Hammarsjköld
}

The celebration of the seventieth anniversary of the International Law Commission has given us the opportunity to pay tribute to the achievements of the Commission in carrying out its mandate to promote the progressive development of international law and its codification. I join all those colleagues who have pointed to the importance and the success of the Commission in shouldering this responsibility, and who have already paid tribute to its members, current and previous.

This morning's topic encourages us to look ahead to future perspective for the International Law Commission and indeed to future challenges and developments facing international law. The Commission itself has taken the view over the years that it should not have to restrict itself to traditional topics, but that it could also consider issues that reflect new developments in international law. This is also an important aspect of the interaction between the Commission and governments.

Today's panel topic, "The Changing Landscape of International Law", begs the question, as a point of departure, to what extent and how that landscape is changing, and what the role of the Commission should be in responding or, indeed, driving change. We benefit of course from the excellent presentations and speeches that were given yesterday, which touched on some of these aspects. We heard from the President of the International Court of Justice and others speak both of the challenges facing international law today and the challenges and potential in the work of the Commission: changes in reality, changes in the actors in international law and developments within the Commission itself. 